Reproducción del artículo publicado en la revista Acta Médica Costarricense.

Rodríguez, L.; Fernández, X. Los frijoles (Phaseolus vulgaris): su aporte a la dieta del costarricense. Acta Medic Costarric 2003; 45:120. Página web: www.scielo.sa.cr

This is a translation of an article published in the journal Acta Médica Costarricense:

Rodríguez, L.; Fernández, X. Beans (Phaseolus vulgaris): Their contribution to the diet of Costa Ricans. Acta Medic Costarric 2003; 45:120. Web page: www.scielo.sa.cr

\title{
LOS FRIJOLES (Phaseolus vulgaris): SU APORTE A LA DIETA DEL COSTARRICENSE ${ }^{1}$
}

\author{
BEANS (Phaseolus vulgaris): \\ THEIR CONTRIBUTION TO THE DIET OF COSTA RICANS 1
}

\author{
Ligia Rodríguez-Castillo², Xinia E. Fernández-Rojas ${ }^{3}$
}

\begin{abstract}
RESUMEN
Los frijoles (Phaseolus vulgaris): su aporte a la dieta del costarricense. Los frijoles constituyen un alimento básico en la dieta del costarricense. Sin embargo, la cantidad y frecuencia con que se consumen ha venido disminuyendo, sobretodo en la zona urbana ${ }^{1}$. Esta tendencia resulta preocupante, ya que el frijol es fuente de proteínas, hierro vegetal, fibra, ácido fólico, tiamina, potasio, magnesio, y zinc ${ }^{2}$. Su aporte a la dieta del costarricense, a pesar de la disminución en su consumo, es importante por su contenido de nutrientes y de fitoquímicos los cuales son de utilidad en la prevención y tratamiento de varias de las patologías que afectan a la población costarricense ${ }^{3}$. La presente revisión, documenta los efectos positivos que algunos nutrientes y otros elementos que aporta el frijol tienen en la prevención y el control de algunas de las enfermedades crónicas que constituyen problemas de salud pública en el país. Se abordan de manera particular la fibra, el ácido fólico y el magnesio. Asimismo, se hace referencia a otras sustancias fitoquímicas, presentes en los frijoles, que constituyen elementos protectores de la salud y que hacen de los frijoles un "alimento funcional". Finalmente, se ofrecen recomendaciones prácticas orientadas a mejorar la digestibilidad de este alimento, de manera que se contribuya a mantener e incrementar su consumo a nivel de los hogares costarricenses.
\end{abstract}

Descriptores: frijoles (Phaseolus vulgaris), valor nutritivo, dieta, enfermedades crónicas, digestibilidad.

1 Recibido en Acta Médica Costarricense: 28 de febrero, 2003. Aceptado: 22 de julio, 2003.

2 Escuela de Nutrición, Universidad de Costa Rica Investigadora principal del "Proyecto Campaña Educativa para Incrementar el Consumo de Frijoles". Email: farodri@ racsa.co.cr

3 Escuela de Nutrición, Universidad de Costa Rica

\begin{abstract}
Beans (Phaseolus vulgaris) are an important part of the Costa Rican diet. Nevertheless, the amount and the frequency of its consumption has been decreasing over time, especially in the urban areas ${ }^{1}$ This tendency is a concern to those involved in health and nutrition since beans are a source of protein, non-heme iron, fiber, folic acid, thiamin, potassium, magnesium and $z_{\text {inc }}{ }^{2}$. The nutritional contribution of beans lo the Costa Rican diet is important in spite of the reduction in consumption. Beans are important because of their nutrient content and the presence of phytochemicals that have been recognized as part of the prevention and treatment of health problems affecting the Costa Rican population ${ }^{3}$. This review documents the positive effects of some of the nutrients and elements present in beans related lo the prevention and control of some chronic diseases of importance in public health. lt includes information on fiber, folic acid and magnesium. Additionally, it considers the presence of phytochemicais that make beans a "functional food". Finally, some practicar recommendations are offered in order lo improve digestibility. Thus, our purpose is to educate the Costa Rican population lo maintain and lo increase the consumption of beans.
\end{abstract}

Key words: beans (Phaseolus vulgaris), nutritional value, diet, chronic diseases, digestibility.

1 Received: February 28, 2003. Accepted: July 22, 2003

2 University of Costa Rica, School of Nutrition. Principal Researcher Project "Educational Campaign to Increase Bean Consumption". E-mail: farodri@ racsa.co.cr

3 University of Costa Rica, School of Nutrition. 


\section{Aporte nutricional de los frijoles a la dieta costarri- cense}

Los frijoles constituyen un alimento básico en la dieta del costarricense. De acuerdo con la Encuesta Nacional de Nutrición de $1996^{1}$ un $96,7 \%$ de los costarricenses consume frijoles. Sin embargo, la cantidad y frecuencia con que se consumen ha venido disminuyendo. En el periodo comprendido entre 1966 y 1996 el consumo promedio de frijol pasó de $57 \mathrm{~g}$ de frijoles/p/día ${ }^{4}$, a un consumo de $31 \mathrm{~g} / \mathrm{p} /$ día en 1996. Dicho consumo es menor en la zona urbana $(28,1 \mathrm{~g} / \mathrm{p} /$ día $)$ que en la rural $(42,9 \mathrm{~g} / \mathrm{p} / \mathrm{día}){ }^{1}$

El frijol es fuente de proteínas, hierro vegetal, fibra, ácido fólico, tiamina, magnesio, potasio y zinc (USDA 2000) $)^{2}$. En la Figura 1, puede observarse el aporte de energía y nutrientes de los frijoles a la dieta del costarricense. Dicho aporte es expresado como porcentaje de las recomendaciones dietéticas diarias (RDD), tomando como base el consumo reportado en la última Encuesta Nacional de Nutrición (1996), y en referencia a los requerimientos de adultos de ambos sexos ${ }^{5}$.

La Figura 1 muestra a los frijoles como importantes contribuyentes a los requerimientos diarios de folatos, magnesio y fibra. En los niveles actuales de consumo, también es significativo el aporte de proteínas, tiamina, hierro y potasio. Cabe hacer notar que, a pesar de la significativa contribución de los frijoles, tanto los folatos como la fibra, siguen siendo deficientes en la población costarricense. ${ }^{6,7}$ Por lo tanto, los profesiona-

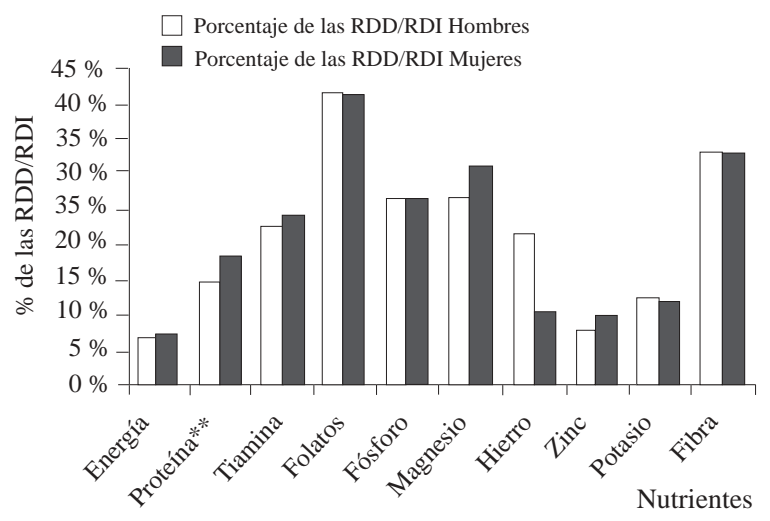

Figura 1. Aporte nutricional del consumo de frijoles a la dieta del costarricense. 1996*.

\footnotetext{
* Los datos se basan en la composición de frijol negro cocido (USDA, 2000. NBD \#16-015).

** Las RDD (Recomendaciones Dietéticas Diarias) se tomaron de: INCAP ${ }^{5}$; para potasio de las DRVS ${ }^{8}$; para fibra de Guías alimentarias 7 para folatos de $\mathrm{FAO} / \mathrm{WH}^{9}$ y para proteína corresponde a $1 \mathrm{~g} / \mathrm{kg}$ de peso ideal / día.
}

\section{Nutritional Contribution of Beans to the Diet of Costa Ricans}

Beans are a staple food in the diet of Costa Ricans. According to the 1996 National Nutrition Survey 1, $96.7 \%$ of Costa Ricans eat beans. However, the amount and frequency in which beans are consumed have been decreasing. The average consumption went from 57 grams of beans/p/day ${ }^{4}$ in 1966, to $31 \mathrm{~g} / \mathrm{p} /$ day in 1996. This figure is even lower in urban areas $(28.1 \mathrm{~g} / \mathrm{p} /$ day $)$ than it is in rural areas $(42.9 \mathrm{~g} / \mathrm{p} /$ day $){ }^{1}$

Beans are a source of protein, non-hemic iron, fiber, folic acid, thiamin, magnesium, potassium and zinc (USDA, 2000) ${ }^{2}$. Beans' energy and nutrient contribution to the diet of Costa Ricans is shown in Figure 1. Such contribution is expressed as a percentage of the recommended dietary allowances (RDA) for adult females and males 5 , according to the consumption reported in the 1996 National Nutrition Survey.

Figure 1 indicates that bean contribution of folic acid, magnesium and fiber to the diet is considerable. At current consumption levels, beans contribution of proteins, thiamin, iron and potassium to the diet is also important. It is worth emphasizing that in spite of beans' substantial contribution to Costa Rican nutrition, a fiber and folic acid deficiency persists among the Costa Rican population.6,7 Therefore, health care professionals must encourage frequent

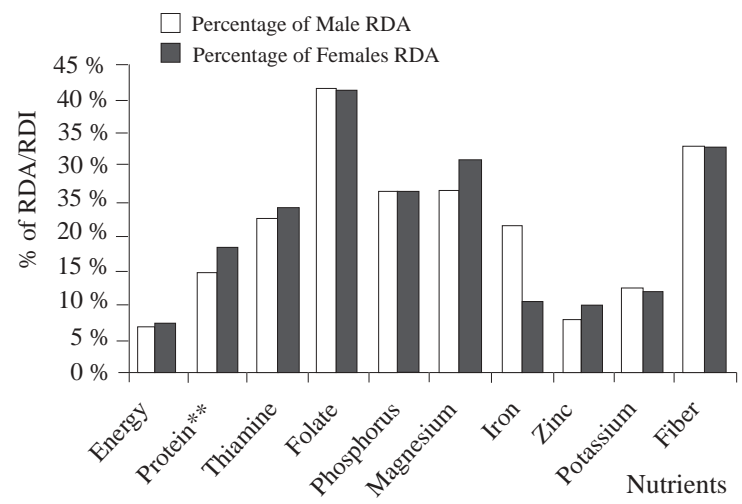

Figure 1. Nutritional, energetic and fiber contribution of beans to the diet of Costa Ricans. 1996*

* Data are based on cooked black beans' nutritional, energetic and fiber content (USDA, 2000. NBD \#16-015).

** RDA (Recommended Daily Allowances) were taken from $\mathrm{INCAP}^{5}$; for potassium, from the $\mathrm{DRVS}^{8}$; for fiber, from the Guías Alimentarias ${ }^{7}$; for folates, from $\mathrm{FAO} / \mathrm{WHO}^{9}$; and for protein it is $1 \mathrm{~g} / \mathrm{kg}$ body-weight/day. 
les de la salud deben estimular al consumo frecuente de frijoles y otros alimentos fuente de fibra y folatos.

\section{Los frijoles contribuyen a prevenir enfermedades crónicas}

Las enfermedades cardiovasculares, la diabetes y el cáncer, constituyen serios problemas de morbimortalidad en el país ${ }^{10}$. Los frijoles contribuyen a la prevención y el tratamiento de estas patologías, tanto por su aporte de micronutrientes (particularmente ácido fólico y magnesio) como por su alto contenido de fibra, aminoácidos azufrados, taninos, fitoestrógenos y aminoácidos no esenciales. Los efectos específicos del ácido fólico y de la fibra han sido ampliamente documentados 11-16. El magnesio también ha sido identificado como un elemento involucrado en estos procesos, aunque su participación no ha sido completamente dilucidada ${ }^{17-19}$. Con respecto a otros elementos y a las interrelaciones bioquímicas que pueden potenciar estos efectos, hay trabajos de investigación que han abordado el alimento como un todo en vez de nutrientes específicos ${ }^{20-22}$.

Seguidamente se describen algunos de los hallazgos alrededor de la fibra, el ácido fólico, y el magnesio y sus correspondientes roles fisiológicos, que explican sus efectos positivos sobre la salud. Asimismo, se plantea la importancia de otros elementos presentes en los frijoles y del alimento en forma integral.

\section{Fibra}

La fibra comprende un grupo heterogéneo de polisacáridos tales como celulosa, hemicelulosa, pectina y de algunas otras sustancias que no corresponden al grupo de carbohidratos tales como la lignina, cuya característica genérica es que no pueden ser digeridos por el organismo humano.

Sin embargo, a través del tracto gastrointestinal pueden interactuar con diferentes elementos y captar agua. Este hecho, hace de la fibra un elemento muy importante en el proceso de la digestión, ya que limita y/o disminuye la velocidad de absorción de algunos nutrientes, y favorece el tránsito intestinal. Dadas estas características, la fibra permite una absorción más lenta de la glucosa, lo cual condiciona índices glicémicos moderados y, por lo tanto contribuye a controlar la hiperinsulinemia ${ }^{14,15}$. Esto tiene efectos benéficos tanto en la prevención como en el tratamiento de la Diabetes Mellitus. Una dieta alta en fibra contribuye a mejorar el perfil lipídico, dado que disminuye la absorción intestinal de ácidos grasos y colesterol, tanto de la dieta como del colesterol reciclado proveniente de la bilis. Por consumption of beans and other sources of fiber and folic acid.

\section{Beans help prevent chronic diseases}

Cardiovascular diseases, diabetes and cancer present very high morbility and mortality rates in this country ${ }^{10}$. Bean consumption helps prevent and treat these pathologies, due to their micro-nutrient contribution to the diet (specially folic acid and magnesium), and to their high fiber, sulphured amino acid, tannin, phyto-estrogen and non-essential amino acid content. The specific effects of folic acid and fiber have been extensively documented ${ }^{11-16}$. Magnesium has also been identified as an element involved in these processes, although its participation has not been entirely explained ${ }^{17-19}$. With respect to other elements and the biochemical interrelations that may potentiate these effects, some researches have addressed this food as a whole, instead of its specific nutrients ${ }^{20-22}$.

Some of the findings with regards to fiber, folic acid and magnesium, and their corresponding physiological roles are described below, and their positive effects on health are explained. Furthermore, the importance of beans in general, as well as that of other elements they contain, is presented.

\section{Fiber}

Fiber comprises a heterogeneous group of polysaccharides such as cellulose, hemicelluloses, pectin, and some other substances not classified as carbohydrates such as lignin, whose general characteristic is that they cannot be digested by the human body.

However, they can interact with different elements through the gastro-intestinal tract, and absorb water. This fact makes fiber a very important element in the digestive process, because it limits absorption or reduces the rate of absorption of some nutrients, decreasing transit time through the intestinal tract. Given these properties, fiber allows a slower absorption of glucose, which determines a moderate glycemic index, thus helping control hyperinsulinemia 14,15. This has beneficial effects in the prevention and treatment of Diabetes Mellitus.

A high-fiber diet contributes to improve the lipid profile, because it helps reduce intestinal absorption of fatty acids and cholesterol, from both the diet and from recycled cholesterol coming from the gall bladder. On the other hand, as an effect of fermentation, soluble 
otra parte, la fibra soluble libera, por efecto de fermentación, ácidos grasos de cadena corta, los cuales parecen ejercer un efecto inhibidor de la síntesis endógena de colesterol ${ }^{23,24}$. Todos esos efectos se refuerzan debido a que, en general, las dietas altas en fibra tienden a ser bajas en grasas y carbohidratos simples ${ }^{19}$. De esta forma, los alimentos ricos en fibra dietética, tales como los frijoles, tienen el potencial de disminuir el riesgo de enfermedad cardiovascular desde diversas rutas: 1) por su efecto reductor del colesterol y los triglicéridos; 2) por su contribución al control glicémico, la Diabetes Mellitus y las complicaciones cardiovasculares asociadas; 3) por su aporte al mantenimiento de un peso adecuado (por la sensación de saciedad que provoca y por la composición de la dieta ya indicada) $14,15,19,23$.

Con respecto a cáncer, numerosos estudios tanto epidemiológicos como experimentales $16,25,26,27$ han demostrado una asociación inversa entre el consumo de fibra y el cáncer de colon. El efecto se explica porque acelera el tránsito intestinal, aumenta el volumen fecal y la frecuencia de defecaciones, así como porque influye en el metabolismo bacteriano, disminuyendo la formación y/o absorción de metabolitos cancerígenos $16,25,26$. Por otra parte, Bruce, Wolever y Giacca ${ }^{27}$, reconociendo que la insulina y los triglicéridos pueden tender a incrementar el crecimiento de lesiones precursoras del cáncer de colon, proponen de nuevo, que el control de la hiperinsulinemia y la menor absorción de grasa, (ambos favorecidos por la fibra) ejercen un efecto protector sobre el cáncer de colon.

Dada la importancia de la fibra, el documento "Guías Alimentarias para Costa Rica"7, recomienda un consumo de $30 \mathrm{~g} / \mathrm{p} / \mathrm{dí}$. Los costarricenses consumen una cantidad de fibra que está por debajo de esa meta. Diversos estudios $28,29,30$ han encontrado niveles de consumo en un rango de 11 a 20,3 g de fibra/p/día, con un promedio de $17 \mathrm{~g} / \mathrm{p} /$ día, en adultos costarricenses; lo cual indica la importancia de promover un mayor consumo de este elemento.

\section{Folatos}

Los folatos intervienen, como parte de un complejo enzimático en los procesos asociados con la reproducción celular. Así, tienen un efecto positivo sobre el mantenimiento de los tejidos, sobretodo de aquellos que requieren de un rápido recambio. Uno de los posibles mecanismos que explican este efecto es la intervención del folato en la metilación de compuestos tales como purinas y timidinas que, si no están disponibles, alteran la integridad y reparación del DNA ${ }^{11}$. Se plantea que estas alteraciones aumentan la carcinogénesis, al afectar la expresión de genes supresores de tumores fiber releases short-chain fatty acids, which seems to have an inhibiting effect on the synthesis of endogenous cholesterol ${ }^{23,24}$. All those effects are reinforced because, in general, high-fiber diets tend to be low in fat and simple carbohydrates ${ }^{19}$.

In this way, foods that are rich in dietetic fiber, such as beans, may potentially reduce risk of cardiovascular diseases in several ways: 1) because of their cholesterol and triglyceride reduction effect; 2) because of their contribution to controlling glycemic levels, Diabetes Mellitus and related cardiovascular complications; 3) because of their contribution to maintaining an adequate body weight (because of the feeling of satiety they produce and the composition of the before mentioned diet). ${ }^{14,15,19,23}$

With regards to cancer, many epidemiological and experimental studies $16,25,26,27$ have proved that there is an inverse relationship between fiber consumption and colon cancer. This effect is explained because fiber speeds up intestinal transit time, increasing fecal volume and bowel movement frequency, as well as because it has an influence on bacterial metabolism, reducing formation or absorption of carcinogenic metabolites 16,25,26. On the other hand, Bruce, Wolever and Giacca 27 , while acknowledging that insulin and triglycerides may tend to increase growth of colon cancer precursor lesions, suggest again that hyperinsulinemia control and a lower fat absorption (both of which are favored by fiber) have a protecting effect against colon cancer.

Given that fiber is so important, the document "Alimentary Guidelines for Costa Rica" 7 (Guías Alimentarias para Costa Rica) recommends a fiber consumption of $30 \mathrm{~g} / \mathrm{p} /$ day. The amount of fiber consumed by Costa Ricans is below this goal. Several studies $28,29,30$ have found fiber consumption levels ranging from 11 to $20.3 \mathrm{~g} / \mathrm{p} /$ day, with an average of 17 $\mathrm{g} / \mathrm{p} / \mathrm{day}$ in the Costa Rican adult population. This indicates that it is important to encourage a greater consumption of this element.

\section{Folate}

As part of an enzymatic complex, folic acid mediates in processes associated with cellular reproduction. In this way, it has a positive effect on tissue preservation, mostly for tissues that require rapid replacement. One of the possible mechanisms explaining this effect is the mediation of folic acid in methylation of compounds such as purines and tymidines that, if not available, destabilize DNA integrity and repair ${ }^{11}$. It has been suggested that these 
y de proto-oncogenes ${ }^{12}$. Esto podría explicar su contribución en la disminución del riesgo de desarrollar cáncer en determinados tejidos. Diversos estudios 26,27 han demostrado una asociación positiva entre niveles altos de folatos y una menor incidencia de cáncer de colon.

Adicionalmente, la deficiencia de folatos provoca un incremento en los niveles de homocisteína, lo cual causa deterioros relacionados con la formación de placas de ateroma ${ }^{13}$. Esto justifica el aporte de los folatos en la prevención de la enfermedad cardiovascular.

En respuesta a todos estos hallazgos, el Grupo de Expertos $\mathrm{FAO} / \mathrm{WHO}$ en requerimientos de vitaminas y minerales del ser humano, en un reporte preliminar, revisado en julio del 2000, recomienda duplicar la RDD de folatos, de 200 a $400 \mathrm{mcg} / \mathrm{p} / \mathrm{día}$. (FAO/WHO, 1998) 9. Los frijoles aportan a la dieta costarricense (con una media de consumo de $31 \mathrm{~g} / \mathrm{p} /$ día; según la Encuesta de $1996^{1}$ ) un $32 \%$ de esa recomendación. Mayores ingestas de folatos podrían ser conseguidas sin suplementación, incrementando el consumo de frijoles.

\section{Magnesio}

El magnesio tiene un papel importante en al menos 300 reacciones enzimáticas esenciales. Posiblemente, debido a esos diversos roles, existen aún contradicciones con respecto a su posible contribución en la prevención y tratamiento de algunas enfermedades ${ }^{18}$. No obstante, es claro que magnesio forma parte de numerosas enzimas, algunas de las cuales constituyen potentes antioxidantes en la cadena respiratoria que lleva a la generación de ATP y agua a nivel de la mitocondria. Además, funciona en la activación de aminoácidos y en la síntesis y degradación del DNA ${ }^{19}$. Estos roles lo identifican como un nutriente importante con respecto a la prevención del cáncer. Por otra parte, el magnesio parece ejercer un efecto protector contra la hipertensión y, consecuentemente, los problemas cardiacos ${ }^{17}$.

\section{Los frijoles son fuente de fitoquímicos}

Además de los efectos ya discutidos de la fibra, los folatos y el magnesio en la prevención de varias de las enfermedades crónicas y degenerativas que afectan a la población costarricense, es necesario también señalar que otras sustancias fitoquímicas presentes en los frijoles, tales como: fitoestrógenos, taninos, aminoácidos sulfurados y un conjunto amplio de aminoácidos no esenciales, también han sido identificados como elementos protectores contra algunos de los factores que estimulan el crecimiento de los tumores. 20,31 alterations increase carcinogenesis by affecting the expression of tumor-suppressor genes and proto-oncogenes. 12 This may explain their contribution in reducing the risk of developing cancer in certain tissues. Several studies 26,27 have shown that there is a positive relationship between high levels of folic acid and a lower incidence of colon cancer.

In addition, a deficiency of folic acid produces an increment in homocysteine levels, which causes deteriorations related with formation of ateromatous plaques. ${ }^{13}$ This justifies folic acid contribution to the prevention of cardiovascular diseases

In response to all these findings, the FAO/WHO Experts Group on human beings' vitamin and mineral requirements, in a preliminary report reviewed in July 2000, recommended to double folic acid RDA, from 200 to $400 \mathrm{mcg} / \mathrm{p} /$ day (FAO/WHO, 1998). ${ }^{9}$ With an average consumption of $31 \mathrm{~g} / \mathrm{p} /$ day - according to the 1996 Survey $^{1}$ - beans provide $32 \%$ of that recommendation to the diet of Costa Ricans. Greater intakes of folic acid may be achieved by increasing bean consumption, without having to supplement foods.

\section{Magnesium}

Magnesium plays important roles in at least 300 essential enzymatic reactions. Probably due to such diverse roles, there are still contradictions with regards to its possible contribution in the prevention and treatment of some diseases ${ }^{18}$. Notwithstanding, it is obvious that magnesium is an integral part of many enzymes, some of which constitute powerful anti-oxidants in the respiratory chain leading to ATP and water generation at the mitochondria level. In addition, it triggers amino acid activation and DNA synthesis and break down ${ }^{19}$. These roles make magnesium an important nutrient in cancer prevention. At the same time, it seems to have a protective effect against hypertension and, consequently, against cardiovascular diseases ${ }^{17}$.

\section{Beans are a source of phyto-chemical substances}

Aside from the effects already discussed of fiber, folic acid and magnesium in the prevention of several of the chronic and degenerative diseases affecting the Costa Rican population, it is also necessary to indicate that other phyto-chemical substances contained in beans such as phyto-estrogens, tannins, sulphured amino acids and a wide variety of non-essential amino acids, have also been identified as protective elements against some of the factors that stimulate tumor growth 20,31 . 
Slavin ${ }^{21}$, al resumir el efecto protector de los granos enteros (leguminosas y cereales integrales) sobre varios tipos de cáncer (gástrico, colon, pecho y próstata), indica los posibles mecanismos: 1) son una fuente concentrada de fibra; 2) son ricos en antioxidantes, incluyendo minerales como el magnesio; 3) son ricos en folatos (las leguminosas); 4) son una fuente de fitoestrógenos que tienen efectos hormonales relacionados con la prevención del cáncer de mama y de próstata y 5) median la respuesta insulínica, lo cual se ha planteado que protege contra el cáncer de colon y el cáncer de mama. Es por eso que las leguminosas, han sido catalogadas como un "alimento funcional"; 32 es decir un alimento que además de nutrientes, aporta otras sustancias que tienen un efecto benéfico sobre la salud 33,34 . Cuando se evalúa el efecto de un alimento sobre la salud, una consideración importante es el sinergismo que puede existir entre sus diferentes elementos constitutivos (nutrientes y no-nutrientes), lo cual puede potenciar o reducir su efecto benéfico ${ }^{32}$. Por esta razón, la comunidad científica ha abordado el estudio no solo de los efectos de componentes aislados, sino también de diferentes alimentos en forma integral.

Con respecto a frijoles, un estudio epidemiológico de Correa ${ }^{35}$, encontró una correlación inversa, altamente significativa entre el consumo de frijoles y la mortalidad ajustada por edad de cáncer de mama $(\mathrm{r}=$ $-0,70)$; cáncer de próstata $(\mathrm{r}=-0,66)$, y cáncer de colon $(\mathrm{r}=-0,68)$. Kolonel et al. ${ }^{36}$ reportaron también una tendencia significativa inversa entre el consumo de leguminosas (excluyendo alimentos de soya) y la incidencia de cáncer de próstata. Hangen y Benninck 22 y Hughes et al. ${ }^{37}$ determinaron, utilizando un modelo animal, que la alimentación con frijoles inhibió la incidencia de tumores químicamente inducidos en el colon.

Considerando la evidencia, diversos autores y entidades reconocidas, recomiendan dietas con una alta proporción de alimentos de origen vegetal, entre las que destacan los vegetales y las frutas $26,38-40$. Con respecto a leguminosas, el Fondo Mundial para la Investigación en Cáncer (World Cancer Research Fund) y el Instituto Americano para la Investigación en Cáncer (The American Institute for Cancer Research) ${ }^{38}$ reconocen como biológicamente plausible un efecto positivo de las leguminosas en la prevención del cáncer, y recomiendan dar prioridad a estudios en que se determine esta relación. La Asociación Americana del Corazón (American Heart Association) presentó recientemente una nueva guía dietética, que hace énfasis en los alimentos más que en los nutrientes y recomienda al menos seis porciones diarias de leguminosas y granos integrales ${ }^{41}$.
Slavin 21 , summarizing the protective effect of whole grains (legumes and whole cereals) on several types of cancer (gastric, colon, breast and prostate cancers), indicates the possible mechanisms: 1) they are a source of concentrated fiber; 2) they are rich in anti-oxidants, including minerals such as magnesium; 3) they are rich in folates (legumes); 4) they are a source of phyto-estrogens that have hormonal effects related to prevention of breast and prostate cancer; and 5) they intervene in the insulin response, which, as has been suggested, protects against colon and breast cancer. For this reason, legumes have been classified as "functional foods"; 32 i.e., foods that, aside from nutrients, provide other healthful substances. 33,34 When the effects of a specific food on health are assessed, an important aspect to consider is the synergism that may exist among its different elements (nutrient and non-nutrient), which may potentiate or reduce its beneficial effects 32 . For this reason, the scientific community has addressed in a comprehensive manner not only the effects of isolated components, but also those of different foods.

With regards to beans, an epidemiological study carried out by Correa ${ }^{35}$, found a highly significant inverse correlation between bean consumption and age-adjusted mortality of breast cancer $(\mathrm{r}--0.70)$; prostate cancer $(\mathrm{r}=-0.66)$, and colon cancer $(\mathrm{r}=-0.68)$. Kolonel et al. ${ }^{36}$ also reported an significant inverse tendency between legume consumption (excluding soy-based foods) and prostate cancer incidence. Based on an animal model, Hangen and Benninck 22 and Hughes et al. ${ }^{37}$, determined that eating beans inhibited the incidence of chemically induced colon tumors.

Considering the evidence, several authors and entities recommend diets with a high proportion of plant foods, among which vegetables and fruits stand out 26,38-40. Regarding legumes, the World Center Research Fund and the The American Institute for Cancer Research ${ }^{38}$ have acknowledged that a positive effect of legumes on cancer prevention is biologically plausible, and recommend giving priority to studies aimed at determining that relationship. Recently, The American Heart Association presented a new dietetic guideline emphasizing on foods rather than on nutrients, and recommending at least six portions of legumes and whole grains per day. ${ }^{41}$

\section{Bean digestion problems and how to solve them}

Regardless of all the advantages pointed out, it is also necessary to acknowledge problems related to 


\section{Los problemas de digestibilidad de los frijoles y co- mo resolverlos}

A pesar de todas las ventajas señaladas, es necesario también reconocer los problemas de digestibilidad y flatulencia que, algunos individuos presentan, al consumir frijoles y que podrían limitar su consumo.

Estos problemas son ocasionados por oligosacáridos no digeribles (rafinosa y estaquiosa) que son fermentados en el colon por bacterias y producen hidrógeno, metano y dióxido de carbono ${ }^{42}$. Sin embargo, es necesario señalar que, esos mismos oligasacáridos, favorecen el crecimiento de bifidobacterias que se ha demostrado que disminuyen el riesgo de cáncer de colon ${ }^{43}$.

Otros factores antinutricionales identificados son las antitripsinas (proteínas que inhiben la acción de la tripsina), y algunos glicósidos. Estos son termolábiles los primeros y volátiles los segundos, lo cual implica que la cocción usual elimina su actividad ${ }^{44}$.Los problemas de digestibilidad de los frijoles pueden ser superados, en la mayor parte de los casos, mediante procedimientos adecuados de preparación y consumo. En Cuadro 1 , se presenta un resumen de algunas recomen- bean digestion and flatulence presented by some individuals, which may limit their consumption.

These problems are caused by non-digestible oligosaccharides (raffinose and stacchyose) that are fermented in the colon by bacteria and produce hydrogen, methane and carbon dioxide. ${ }^{42}$ However, it is also necessary to indicate that those same oligasaccharides favor growth of bifido bacteria which, as has been proven, reduce the risk of colon cancer ${ }^{43}$.

Other anti-nutritional factors identified are trypsin inhibitors and some glycosides. The former are thermo-labil and the latter are volatile, which means that usual cooking counters their action ${ }^{44}$. In most cases, bean digestion problems may be overcome by applying adequate procedures when cooking and consuming them. A summary of some recommendations to avoid these problems and preserve their nutritional value is presented in Table 1.

In conclusion, bean contribution of nutrients, fiber and phyto-chemicals to the diet may be increased by promoting their consumption, thus improving nutrition and prevention of some of the health problems

Cuadro 1. Recomendaciones prácticas para preservar el valor nutritivo de los frijoles y evitar los problemas de flatulencia.

\begin{tabular}{|c|c|c|}
\hline Para preservar el valor nutritivo & $\begin{array}{l}\text { Para evitar flatulencia y mejorar } \\
\text { la digestión }\end{array}$ & Otras recomendaciones \\
\hline $\begin{array}{l}\text { 1. Deje los frijoles en remojo por lo menos } \\
\text { por } 8 \text { horas. } 45 \text {. Dejarlos la noche anterior } \\
\text { del día de la cocción es una práctica sen- } \\
\text { cilla. Para mayor preservación de nu- } \\
\text { trientes no elimine el agua de remojo. } \\
\text { 2. Cocine preferiblemente en "olla mágica". } \\
\text { La cocción rápida contribuye a conservar } \\
\text { nutrientes. } 46 \\
\text { 3. Cocine sin sal, hasta máxima suavidad o } \\
\text { al gusto del consumidor. Agregue la sal } \\
\text { y/o otros condimentos hasta el final de la } \\
\text { cocción } \\
\text { 4. Ya cocinados, separe los frijoles en por- } \\
\text { ciones del tamaño que usted considere son } \\
\text { suficientes para } 1 \text { día. } 45 \text { Deje enfriar a } \\
\text { temperatura ambiente y coloque en el re- } \\
\text { frigerador los que necesita para dos días. } \\
\text { El resto congélelos en envases cerrados } \\
\text { 5. Descongele los frijoles del día y caliente } \\
\text { solamente, cuando vaya a consumirlos. } \\
\text { Evite recalentar los frijoles una y otra } \\
\text { vez. } \\
\text { 6. Estas prácticas preservan el valor } \\
\text { nutritivo del frijol, especialmente del } \\
\text { ácido fólico y la tiamina que se pierden } \\
\text { por exposición prolongada al calor.46,47 }\end{array}$ & $\begin{array}{l}\text { 1. Mastique muy bien. La digestión se } \\
\text { inicia en la boca. } \\
\text { 2. Introduzca los frijoles gradualmente en } \\
\text { su dieta, especialmente si tiene mucho } \\
\text { tiempo de no consumirlos } \\
\text { 3. Si el frijol entero causa problemas, aun } \\
\text { después de haber sido remojado y estar } \\
\text { bien cocinado, trate consumiéndolos } \\
\text { molidos o licuados } \\
\text { 4. Revise la forma de preparación y pruebe } \\
\text { eliminando salsas, cominos, pimienta y } \\
\text { grasa. Esto reduce agentes que pueden } \\
\text { ser irritantes del tracto gastrointestinal. }{ }^{45} \\
\text { 5. Pruebe también preparando frijoles rojos } \\
\text { en vez de negros. Los primeros han } \\
\text { demostrado ser más digeribles. } 48 \\
\text { 6. Sólo si los problemas de flatulencia o } \\
\text { disconformidad intestinal persisten, } \\
\text { elimine el agua de remojo y agregue } \\
\text { agua limpia para cocinar. } 49\end{array}$ & $\begin{array}{l}\text { 1. Para la alimentación infantil, utilice el } \\
\text { frijol entero, molido o licuado. El caldo } \\
\text { de frijol, sin frijoles, no es una adecuada } \\
\text { fuente de nutrientes para este grupo de } \\
\text { edad. } 50 \\
\text { 2. Pruebe nuevas alternativas y recetas para } \\
\text { la preparación de frijoles para la familia. } \\
45\end{array}$ \\
\hline
\end{tabular}


Table 1. Practical recommendations to preserve the nutritional value of beans and avoid flatulence.

\begin{tabular}{|c|c|c|}
\hline To preserve nutritional value & To avoid flatulence and improve digestion & Other recommendations \\
\hline $\begin{array}{l}\text { 1. Soak beans for at least } 8 \text { hours. }{ }^{45} \text { Leaving } \\
\text { them in water since the night before } \\
\text { cooking them is a simple practice. For } \\
\text { greater nutrient preservation, do not } \\
\text { throw away soaking water. } \\
\text { 2. Cook beans preferably in pressure } \\
\text { cooker. Rapid cooking helps preserve } \\
\text { nutrients. } 46 \\
\text { 3. Cook beans without salt until they are } \\
\text { soft enough. Then add salt and/or other } \\
\text { seasonings until they are completely } \\
\text { cooked } \\
\text { 4. Once they are cooked, divide beans in } \\
\text { portions containing enough beans to eat } \\
\text { in one day. } 45 \text { Let cool dawn at room } \\
\text { temperature and store in the refrigerator } \\
\text { the amount to eat in two days. Then } \\
\text { freeze the rest in sealed containers. } \\
\text { 5. Defrost the beans to eat during one day } \\
\text { and heat them up only when they are to } \\
\text { be eaten. Avoid reheating the beans. } \\
\text { 6. These practices preserve beans' } \\
\text { nutritional value, particularly that of folic } \\
\text { acid and thiamine which are lost when } \\
\text { beans are subjected to prolonged } \\
\text { heat.. } 46,47\end{array}$ & $\begin{array}{l}\text { 1. Chew very well. Digestion starts in the } \\
\text { mouth. } \\
\text { 2. Introduce beans to your diet gradually, } \\
\text { especially if you have not eaten beans for } \\
\text { a long time. } \\
\text { 3. If whole beans give you problems even } \\
\text { when they have been soaked before } \\
\text { cooking them, and they are well cooked, } \\
\text { try to eat them mashed or blended. } \\
\text { 4. Think over the way to prepare beans and } \\
\text { try eliminating salsas, cumin, black } \\
\text { pepper and fat. This reduces the amount } \\
\text { of agents that may irritate the intestinal } \\
\text { tract. } 45 \\
\text { 5. Try making red instead of black beans. } \\
\text { Red beans have proven to be more } \\
\text { digestible. }{ }^{48} \\
\text { 6. Only if digestive and flatulence problems } \\
\text { persist, throw away the soaking water } \\
\text { and add clean water to cook the beans. }{ }^{49}\end{array}$ & $\begin{array}{l}\text { 1. Use mashed or blended beans for infants. } \\
\text { The bean broth by itself (without beans) } \\
\text { is not an adequate source of nutrients for } \\
\text { infants. } 50 \\
\text { 2. Try out new alternatives and recipes to } \\
\text { prepare beans for your family } 45\end{array}$ \\
\hline
\end{tabular}

daciones para evitar estos problemas y para preservar el potencial nutritivo de este alimento.

En conclusión, al promover el consumo de frijoles, se podría incrementar el aporte de nutrientes, fibra y fitoquímicos importantes que contiene este alimento, lo que contribuiría al mejoramiento de la alimentación y a la prevención de algunos de los problemas de salud que actualmente afectan la población costarricense. Además, se contribuiría con el rescate de un alimento que forma parte de nuestra cultura y seguridad alimentaria.

Es por eso que la Escuela de Nutrición ha desarrollado el proyecto "Campaña educativa para la promoción del consumo de frijoles en una comunidad urbana"; el cual ha generado diversas publicaciones, materiales educativos $3,45,51,52,53,54$ y experiencias de utilidad para la promoción del consumo de este alimento de interés nacional.

\section{Agradecimientos y colaboraciones}

Este artículo se elabora dentro del marco del Programa "Bean Cowpea Collaborative Research currently affecting the Costa Rican population. In addition, a contribution would be made to restore part of this country's alimentary culture and food assurance.

For those reasons, the Nutrition School developed the Project "Educational Campaign to Increase Bean Consumption in an Urban Community", through which several useful publications and educational materials have been issued $3,45,51,52,53,54$. It also provided valuable experiences that might help promote consumption of this food that is so important for the nutritional and health status of the Costa Rican population.

\section{Acknowledgements and collaborations}

This article was made within the framework of the Bean Cowpea Collaborative Research Program, fund DAN -GSS-860008-88 AID. Said program finances the Macro-Project "Digestibility of Common Beans", carried out by the Centro Nacional de Investigación en Tecnología de Alimentos (CITA) (the Food Technology National Research Center) from the University of Costa Rica. As part of this macro-project, the 
Program”, fondo DAN-GSS-860008-88 AID. Dicho programa apoya al proyecto macro "Digestibilidad del Frijol Común", a cargo del Centro Nacional de Investigación en Tecnología de Alimentos (CITA) de la UCR. Como parte de ese proyecto macro, la Escuela de Nutrición de la Universidad de Costa Rica, ha venido trabajando en la transferencia tecnológica y educación nutricional al consumidor.

\section{REFERENCIAS}

1. Ministerio de Salud. Encuesta Nacional de Nutrición Fascículo 3: Consumo Aparente. San José, Costa Rica: Ministerio de Salud; 1996.

2. U.S. Department of Agriculture. Base de datos sobre composición de alimentos. http://www.nal.usda/fnic; 2000 .

3. Campos E, Fernández A, Sánchez I, Sancho T, y Villalobos C. Diagnóstico para el diseño de una campaña educativa tendiente a incrementar el consumo de frijol en una comunidad urbana de clase media de San José. Seminario de Licenciatura. San José, Costa Rica: Universidad de Costa Rica; 1999.

4. INCAP/ICNND/ Ministerio de Salubridad Pública de Costa Rica. Evaluación Nutricional de la Población de Centroamérica y Panamá: Costa Rica. Publicación INCAP-V-28. Guatemala, Guatemala: INCAP; 1969.

5. Torún B, Menchú M, Elías L. Recomendaciones Dietéticas Diarias del INCAP: Edición XLV Aniversario. Publicación INCAP ME/057. Guatemala: INCAP; 1996.

6. Ministerio de Salud/INCIENSA. Encuesta Nacional de Nutrición Fascículo 2: Micronutrientes. San José, Costa Rica: Ministerio de Salud; 1996.

7. Muñoz L, Murillo S; ed. Guías de Alimentación: Lineamientos metodológicos y criterios técnicos. San José, Costa Rica: INCAP/OPSUCR; 1995.

8. Whitmire, S.J. Water, Electrolyte and Acid-base Balance. En: Mahan, K and Escott-Stump. Krause's Food, Nutrition and Dietherapy. 10th Ed. Philadelphia, USA: Saunders Pub, 2000. p. 159

9. FAO/WHO (1998). Preliminary Report on Recommended Intakes of the Joint FAO/WHO Expert Consultation Group on Human Vitamin and Mineral Requirements. Reviewed July 2000. http://www.fao.org/.

10. Sáenz, L. Evolution of an Epidemiological Profile. In: Muñoz C y Serimshaw N, ed. The Nutrition and Health Transition of Democratic Costa Rica. Boston, USA: International Foundation for Developing Countries; 1995. p. 119-143.
University of Costa Rica's Nutrition School has been working on technology transfer to and nutritional education for consumers.

\section{REFERENCES}

1. Ministerio de Salud. Encuesta Nacional de Nutrición Fascículo 3: Consumo Aparente. San José, Costa Rica: Ministerio de Salud; 1996.

2. U.S. Department of Agriculture. Base de datos sobre composición de alimentos. http://www.nal.usda/fnic; 2000.

3. Campos E, Fernández A, Sánchez I, Sancho T, y Villalobos C. Diagnóstico para el diseño de una campaña educativa tendiente a incrementar el consumo de frijol en una comunidad urbana de clase media de San José. Seminario de Licenciatura. San José, Costa Rica: Universidad de Costa Rica; 1999.

4. INCAP/ICNND/ Ministerio de Salubridad Pública de Costa Rica. Evaluación Nutricional de la Población de Centroamérica y Panamá: Costa Rica. Publicación INCAP-V-28. Guatemala, Guatemala: INCAP; 1969.

5. Torún B, Menchú M, Elías L. Recomendaciones Dietéticas Diarias del INCAP: Edición XLV Aniversario. Publicación INCAP ME/057. Guatemala: INCAP; 1996.

6. Ministerio de Salud/INCIENSA. Encuesta Nacional de Nutrición Fascículo 2: Micronutrientes. San José, Costa Rica: Ministerio de Salud; 1996.

7. Muñoz L, Murillo S; ed. Guías de Alimentación: Lineamientos metodológicos y criterios técnicos. San José, Costa Rica: INCAP/OPSUCR; 1995.

8. Whitmire, S.J. Water, Electrolyte and Acid-base Balance. En: Mahan, K and Escott-Stump. Krause's Food, Nutrition and Dietherapy. 10th Ed. Philadelphia, USA: Saunders Pub, 2000. p. 159

9. FAO/WHO (1998). Preliminary Report on Recommended Intakes of the Joint FAO/WHO Expert Consultation Group on Human Vitamin and Mineral Requirements. Reviewed July 2000. http://www.fao.org/.

10. Sáenz, L. Evolution of an Epidemiological Profile. En: Muñoz C y Serimshaw N, ed. The Nutrition and Health Transition of Democratic Costa Rica. Boston, USA: International Foundation for Developing Countries; 1995. p. 119-143.

11. Suárez, M.R Acido Fólico: Nutriente Redescubierto. Acta Médica Costarricence 2003; 45(1):5-9.

12. Sang-Woon, Choi, Mason, J. Folate and carcinogenesis: and integrated scheme. J.Nutr 2002; 132(2):129-133. 
11. Suárez, M.R Acido Fólico: Nutriente Redescubierto. Acta Médica Costarricence 2003; 45(1):5-9

12. Sang-Woon, Choi, Mason, J. Folate and carcinogenesis: and integrated scheme. J.Nutr 2002; 132(2):129-133.

13. Beresford S, Boushey C. Homocysteine, Folic Acid and Cardiovascular Disease Risk. En: Bendich A y Deckelbaum R, ed. Preventive Nutrition. New Jersey, USA: Humana Press; 1997. p. 193-224

14. Ludwig D, Pereira M, Kroenke C, Hilner J, Van-Hom L, Slattery $\mathrm{M}$ et al. Dietary fiber, weight gain, and cardiovascular disease risk factors in young adults. J Am Med Assoc 1999; 282: 1539 - 1546.

15. Chandalia M, Gar A, Lutjohann D, Von Bergmahn K, Gundry S, Brirkelley L. Beneficial Effects of Dietary Fiber intake in Patients with Type 2 Diabetes Mellitus. New Eng J Med 2000; 342 (19):1440-1441.

16. Reddy B. Prevention of colon carcinogenesis by components of dietary fiber. Anticancer Res 1999; 19(5A): 3681-3.

17. Polisso G, Barbagallo M. Hypertension, diabetes mellitus and insulin resistance: the role of intracellular magnesium. Am J Hyperten 1997; 10: 346-355.

18. Laurant P, Touyz R. Physiological and Pathophysiological Role of Magnesium in the Cardiovascular System: Implications in Hypertension. J Hipertens 2000; 18 (9): 1171-1191.

19. Whitney E, Rolfes S. Understanding Normal and Clinical Nutrition. 8' Ed. USA: Wadsworth Publishing Company; 1999.

20. Messina M. Legumes and soybeans: overview of their nutritional profiles and health effects. Am J Cl Nut 1995; 70 (3 Suppl.) 439S-450S.

21. Slavin J. Mechanisms for the Impact of Whole Grain Foods on Cancer Risk. J Am Coll Nutr 2000; 19 (3 suppl):300S-307S.

22. Hangen L y Bennink M.R. Consumption of Phaseolus vulgaris (Black Beans or Navy beans) Reduces Colon Cancer in Rats. FASEB J 2001; 15: A61.

23. Bourges-Rodríguez H. Aterosclerosis. En: Casanueva E, Kaufer-Horwitz A, Pérez-Lizaur M y Arroyo P, ed. Nutriología Médica. Publicación de la Fundación Mexicana para la Salud. México D.F.: Editorial Médica Panamericana S.A. 1996. p. 232-254.

24. Mahan L, Escott-Stump S. Nutrición y Dietoterapia de Krause. $10^{\circ}$ Ed. México: MacGraw-Hill Interamericana; 2000.

25. Grasten S, Juntunnen K, Poutanen K, Gylling H, Miettinen T, Mykkanen H. Rye bread improves bowel function
13. Beresford S, Boushey C. Homocysteine, Folic Acid and Cardiovascular Disease Risk. En: Bendich A y Deckelbaum R, ed. Preventive Nutrition. New Jersey, USA: Humana Press; 1997. p. 193-224

14. Ludwig D, Pereira M, Kroenke C, Hilner J, Van-Hom L, Slattery $\mathrm{M}$ et al. Dietary fiber, weight gain, and cardiovascular disease risk factors in young adults. J Am Med Assoc 1999; 282: 1539 - 1546.

15. Chandalia M, Gar A, Lutjohann D, Von Bergmahn K, Gundry S, Brirkelley L. Beneficial Effects of Dietary Fiber intake in Patients with Type 2 Diabetes Mellitus. New Eng J Med 2000; 342 (19):1440-1441.

16. Reddy B. Prevention of colon carcinogenesis by components of dietary fiber. Anticancer Res 1999; 19(5A): 3681-3.

17. Polisso G, Barbagallo M. Hypertension, diabetes mellitus and insulin resistance: the role of intracellular magnesium. Am J Hyperten 1997; 10: 346-355.

18. Laurant P, Touyz R. Physiological and Pathophysiological Role of Magnesium in the Cardiovascular System: Implications in Hypertension. J Hipertens 2000; 18 (9): 1171-1191.

19. Whitney E, Rolfes S. Understanding Normal and Clinical Nutrition. 8' Ed. USA: Wadsworth Publishing Company; 1999.

20. Messina M. Legumes and soybeans: overview of their nutritional profiles and health effects. Am J Cl Nut 1995; 70 (3 Suppl.) 439S-450S.

21. Slavin J. Mechanisms for the Impact of Whole Grain Foods on Cancer Risk. J Am Coll Nutr 2000; 19 (3 suppl):300S-307S.

22. Hangen L y Bennink M.R. Consumption of Phaseolus vulgaris (Black Beans or Navy beans) Reduces Colon Cancer in Rats. FASEB J 2001; 15: A61.

23. Bourges-Rodríguez H. Aterosclerosis. En: Casanueva E, Kaufer-Horwitz A, Pérez-Lizaur M y Arroyo P, ed. Nutriología Médica. Publicación de la Fundación Mexicana para la Salud. México D.F.: Editorial Médica Panamericana S.A. 1996. p. 232-254.

24. Mahan L, Escott-Stump S. Nutrición y Dietoterapia de Krause. $10^{\circ}$ Ed. México: MacGraw-Hill Interamericana; 2000.

25. Grasten S, Juntunnen K, Poutanen K, Gylling H, Miettinen T, Mykkanen H. Rye bread improves bowel function and decreases the concentrations of some compounds that are putative colon cancer risk markers in middleaged women and men. J Nutr 2000; 130(9):2215-21.

26. Bostic R. Diet and Nutrition in the Etiology and Primary Prevention of Colon Cancer. En: Bendich A y Deckelbaum 
and decreases the concentrations of some compounds that are putative colon cancer risk markers in middleaged women and men. J Nutr 2000; 130(9):2215-21.

26. Bostic R. Diet and Nutrition in the Etiology and Primary Prevention of Colon Cancer. En: Bendich A y Deckelbaum R, ed. Preventive Nutrition. New Jersey, USA: Humana Press, 1997. p. 57-95.

27. Bruce W, Wolever T, Giacca A. Mechanisms linking diet and colorectal cancer: the possible role of insulin resistance. Nutr Cancer 2000; 37 (1):19-26.

28. Arauz A, Monge R, Muñoz L, Rojas M. La dieta como factor de riesgo de la enfermedad cardiovascular en habitantes del área metropolitana. San José, Costa Rica. Arch Latinoam Nutr 1991; 41: 350-362.

29. Quintana R. Características de la dieta en relación con enfermedad cardiovascular en el Distrito la Fortuna de San Carlos. Tesis de Licenciatura. San José, Costa Rica: Universidad de Costa Rica; 1994.

30. INCAP/OPS/COOPESAIN. Diagnóstico de factores de riesgo cardiovascular en el cantón de Tibás. San José, Costa Rica: EBAIS B 1; 1995.

31. Mc Carty, M. Vegan protein may reduce risk of cancer, obesity and cardiovascular disease by promoting increased glueagon activity. Med Hypothes 1999; 53(6): 45985 .

32. Sedó, R Alimentos Funcionales: análisis general acerca de las características químico-nutricionales, desarrollo industrial y legislación alimentaria. Rey. Costarricense de Salud Pública 2001; 10 (18 y 19) 34-39.

33. Sedó R El mercado de alimentos funcionales y los nuevos retos para la educación alimentaria nutricional. Rev Costarricense de Salud Pública 2002; 11(20): 18-25.

34. ADA. Functional foods-Position of ADA. J Am Diet Assoc. 1999 ; (99): 1278-1285.

35. Correa R Epidemiological correlations between diet and cancer frequency. Cancer Res 1981; 41: 3685-90

36. Kolonel L, Hankin J, Whittemore A, Wu A, Gallagher R, Wilkens L et al. Vegetables, fruits, legumes and prostate cancer: a multiethnic casecontrol study. Cancer Epidemiol Biomark Prev 2000; 9:795-804.

37. Hughes J, Ganthavom C, Wilson L, Sander S. Dry beans inhibit Asoxymethane-induced colon carcinogenesis in F344 rats. J Nutr 1997; 127 (12): 2328-33.

38. World Cancer Rescarch Fund and American Institute for Cancer Research. Food, Nutrition and the Prevention of Cancer: A Global Perspective. USA: World Cancer Re-
R, ed. Preventive Nutrition. New Jersey, USA: Humana Press, 1997. p. 57-95.

27. Bruce W, Wolever T, Giacca A. Mechanisms linking diet and colorectal cancer: the possible role of insulin resistance. Nutr Cancer 2000; 37 (1):19-26.

28. Arauz A, Monge R, Muñoz L, Rojas M. La dieta como factor de riesgo de la enfermedad cardiovascular en habitantes del área metropolitana. San José, Costa Rica. Arch Latinoam Nutr 1991; 41: 350-362.

29. Quintana R. Características de la dieta en relación con enfermedad cardiovascular en el Distrito la Fortuna de San Carlos. Tesis de Licenciatura. San José, Costa Rica: Universidad de Costa Rica; 1994.

30. INCAP/OPS/COOPESAIN. Diagnóstico de factores de riesgo cardiovascular en el cantón de Tibás. San José, Costa Rica: EBAIS B 1; 1995.

31. Mc Carty, M. Vegan protein may reduce risk of cancer, obesity and cardiovascular disease by promoting increased glueagon activity. Med Hypothes 1999; 53(6): 45985 .

32. Sedó, R Alimentos Funcionales: análisis general acerca de las características químico-nutricionales, desarrollo industrial y legislación alimentaria. Rey. Costarricense de Salud Pública 2001; 10 (18 y 19) 34-39.

33. Sedó R El mercado de alimentos funcionales y los nuevos retos para la educación alimentaria nutricional. Rev Costarricense de Salud Pública 2002; 11(20): 18-25.

34. ADA. Functional foods-Position of ADA. J Am Diet Assoc. 1999; (99): 1278-1285.

35. Correa R Epidemiological correlations between diet and cancer frequency. Cancer Res 1981; 41: 3685-90

36. Kolonel L, Hankin J, Whittemore A, Wu A, Gallagher R, Wilkens L et al. Vegetables, fruits, legumes and prostate cancer: a multiethnic casecontrol study. Cancer Epidemiol Biomark Prev 2000; 9:795-804.

37. Hughes J, Ganthavom C, Wilson L, Sander S. Dry beans inhibit Asoxymethane-induced colon carcinogenesis in F344 rats. J Nutr 1997; 127 (12): 2328-33.

38. World Cancer Rescarch Fund and American Institute for Cancer Research. Food, Nutrition and the Prevention of Cancer: A Global Perspective. USA: World Cancer Research Fund/American Institute for Cancer Researeh; 1997.

39. Ji B, Chow W, Yang G, McLaughlin J, Zheng W, Shu X, et al. Dietary Habits and Stomach Cancer in Shanghai, China. Int J Cancer 1998; 76 (5): 659-64. 
search Fund/American Institute for Cancer Researeh; 1997.

39. Ji B, Chow W, Yang G, McLaughlin J, Zheng W, Shu X, et al. Dietary Habits and Stomach Cancer in Shanghai, China. Int J Cancer 1998; 76 (5): 659-64.

40. Cornee J, Pobel D, Riboli E, Guyander M, Hemon B. A Case-control Study of Gastric Cancer and Nutritional Factors in Marseille, France. Eur J Epidemiol 1995; 11 (1): 55-56.

41. Hopkins,J. US Herat Doctors Recommend New Dietary Guidelines. Br Med J 2000; 321:918.

42. Messina M. Legumes and soybeans: Overview of their nutritional profiles and Health Effects. Am J Cl Nut 1999; (Suppl) 70: 439S-50S.

43. Sanders M. Probiotics: a publication of the Institute of Food Technologists Expert Panel on Food Safety and Nutrition. Food technology 1999; 53 (11): 67-76.

44. Sánchez L, Sedó P. Manual de Laboratorio Curso Alimentos 1 (NU1006). San José, Costa Rica: Universidad de Costa Rica, Facultad de Medicina, Escuela de Nutrición; 1998.

45. Dumani M, Rodríguez S. De Todo con Frijoles. San José, Costa Rica: Universidad de Costa Rica, Escuela de Nutrición, CITA-Programa Bean Cowpea CRSP-AID; 2000.

46. Fox B, Cameron A. Ciencia de los Alimentos, Nutrición y Salud. México: Editorial Limusa; 1999.

47. Augustin J, Beck A, Kalbfleish N, Kagel L, Mattehews $\mathrm{R}$. Variation in the vitamin and mineral content of raw and cooked commercial Phaseolus vulgaris classes. J Food Science 1981; 46: 1701-06.

48. Poletti R, Torelli G. Evaluación de características tecnológicas y nutricionales de 12 variedades negras y 12 variedades rojas de frijol (Phaseolus vulgaris) como complemento de los criterios de selección. Proyecto de licenciatura. San José, Costa Rica: Universidad de Costa Rica: 1985.

49. Víquez E. Determinación de los principales polisacáridos no almidonosos causantes de flatulencia en el frijol común. Efecto de la adición de una pectinasa y una celulasa sobre su digestibilidad y aceptabilidad. Tesis de Magíster Scientac. San José, Costa Rica: Universidad de Costa Rica; 1999.

50. Ulate E. Grasas y Deficiencias Nutricionales. En: Fernández, X. ed. Memorias Seminario Grasas y Alimentación Humana. San José, Costa Rica: Litografía Raval, 1994. p. 17-31.

51. Martínez, T; Murillo, A; Rodríguez, S y Páez, P. (2000). Elaboración de los Contenidos de los Mensajes de una
40. Cornee J, Pobel D, Riboli E, Guyander M, Hemon B. A Case-control Study of Gastric Cancer and Nutritional Factors in Marseille, France. Eur J Epidemiol 1995; 11 (1): $55-56$.

41. Hopkins,J. US Herat Doctors Recommend New Dietary Guidelines. Br Med J 2000; 321:918.

42. Messina M. Legumes and soybeans: Overview of their nutritional profiles and Health Effects. Am J Cl Nut 1999; (Suppl) 70: 439S-50S.

43. Sanders M. Probiotics: a publication of the Institute of Food Technologists Expert Panel on Food Safety and Nutrition. Food technology 1999; 53 (11): 67-76.

44. Sánchez L, Sedó P. Manual de Laboratorio Curso Alimentos 1 (NU1006). San José, Costa Rica: Universidad de Costa Rica, Facultad de Medicina, Escuela de Nutrición; 1998.

45. Dumani M, Rodríguez S. De Todo con Frijoles. San José, Costa Rica: Universidad de Costa Rica, Escuela de Nutrición, CITA-Programa Bean Cowpea CRSP-AID; 2000.

46. Fox B, Cameron A. Ciencia de los Alimentos, Nutrición y Salud. México: Editorial Limusa; 1999.

47. Augustin J, Beck A, Kalbfleish N, Kagel L, Mattehews $\mathrm{R}$. Variation in the vitamin and mineral content of raw and cooked commercial Phaseolus vulgaris classes. J Food Science 1981; 46: 1701-06.

48. Poletti R, Torelli G. Evaluación de características tecnológicas y nutricionales de 12 variedades negras y 12 variedades rojas de frijol (Phaseolus vulgaris) como complemento de los criterios de selección. Proyecto de licenciatura. San José, Costa Rica: Universidad de Costa Rica: 1985.

49. Víquez E. Determinación de los principales polisacáridos no almidonosos causantes de flatulencia en el frijol común. Efecto de la adición de una pectinasa y una celulasa sobre su digestibilidad y aceptabilidad. Tesis de Magíster Scientac. San José, Costa Rica: Universidad de Costa Rica; 1999.

50. Ulate E. Grasas y Deficiencias Nutricionales. En: Fernández, X. ed. Memorias Seminario Grasas y Alimentación Humana. San José, Costa Rica: Litografía Raval, 1994. p. 17-31.

51. Martínez, T; Murillo, A; Rodríguez, S y Páez, P. (2000). Elaboración de los Contenidos de los Mensajes de una Campaña Educativa para Aumentar el Consumo de Frijoles en una Comunidad Urbana de Clase Media. Seminario de Licenciatura. San José, Costa Rica: Universidad de Costa Rica.

52. Rodríguez, L.; Dumani, M. (2000 a). Diagnóstico para una Campaña Educativa para la Promoción del Consumo 
Campaña Educativa para Aumentar el Consumo de Frijoles en una Comunidad Urbana de Clase Media. Seminario de Licenciatura. San José, Costa Rica: Universidad de Costa Rica.

52. Rodríguez, L.; Dumani, M. (2000 a). Diagnóstico para una Campaña Educativa para la Promoción del Consumo de Frijoles. En: Libro de Resúmenes de Trabajos Libres del XII Congreso Latinoamericano de Nutrición; SLAN 2000. Buenos Aires, Argentina: Secretaría Científica CESNI.

53. Rodríguez, L y Dumani M. (2000 b). Campaña Educativa con Respecto al Consumo de Frijoles. En: Memorias del IV Taller Anual de Resultados de Investigación y Transferencia de Tecnología PITTA-Frijol. Ed. Por Revista Agronomía Mesoamericana. San José, Costa Rica: Profrijol.

54. Rodríguez, L, Dumani, M, Páez, P e Invancovich, C. (2002). Informe Julio del 2002 del Proyecto "Campaña Educativa para promocionar el Consumo de Frijoles". San José, Costa Rica: Universidad de Costa Rica, Facultad de Medicina, Escuela de Nutrición. Documento impreso. de Frijoles. En: Libro de Resúmenes de Trabajos Libres del XII Congreso Latinoamericano de Nutrición; SLAN 2000. Buenos Aires, Argentina: Secretaría Científica CESNI.

53. Rodríguez, L y Dumani M. (2000 b). Campaña Educativa con Respecto al Consumo de Frijoles. En: Memorias del IV Taller Anual de Resultados de Investigación y Transferencia de Tecnología PITTA-Frijol. Ed. Por Revista Agronomía Mesoamericana. San José, Costa Rica: Profrijol.

54. Rodríguez, L, Dumani, M, Páez, P e Invancovich, C. (2002). Informe Julio del 2002 del Proyecto "Campaña Educativa para promocionar el Consumo de Frijoles". San José, Costa Rica: Universidad de Costa Rica, Facultad de Medicina, Escuela de Nutrición. Documento impreso. 